\title{
Aloe sharoniae N.R.Crouch \& Gideon F.Sm. (Asphodelaceae): species rank for a leptoaloe from southern Africa
}

\author{
Neil R. Crouch $h^{1,2}$ and Gideon F. Smith $3,4,5$ \\ ${ }^{1}$ Ethnobotany Unit, South African National Biodiversity Institute, P.O. Box 52099, Berea Road, 4007 Durban. \\ ${ }^{2}$ School of Chemistry, University of KwaZulu-Natal, 4041 Durban. (email: n.crouch@ @anbi.org.za). \\ ${ }^{3}$ Office of the Chief Director: Biosystematics Research \& Biodiversity Collections, South African National \\ Biodiversity Institute, Private Bag X101, Pretoria, 0001 South Africa. \\ ${ }^{4}$ H.G.W.J. Schweickerdt Herbarium, Department of Plant Science, University of Pretoria, Pretoria, 0002 \\ South Africa. \\ ${ }^{5}$ Centre for Functional Ecology, Departamento de Ciências da Vida, Universidade de Coimbra, 3001-455 \\ Coimbra, Portugal. (email: g.smith@ sanbi.org.za).
}

Summary: A new species of Aloe L., Aloe sharoniae N.R.Crouch \& Gideon F.Sm., is recognised from northern KwaZulu-Natal, South Africa and Swaziland. This taxon was previously known as A. cooperi Baker subsp. pulchra Glen \& D.S.Hardy but is here elevated to the rank of species. From A. cooperi Baker it differs in having leaves that are consistently devoid of teeth in the upper $2 / 3$ of its leaf margins and basally covered below with white, tuberculate maculations. These leaves are further always strongly keeled and arranged distichously. Plants typically present both fewer leaves, and fewer flowers per inflorescence than typical $A$. cooperi.

Zusammenfassung: Aus dem nördlichen KwaZuluNatal (Südafrika) und Swaziland wird eine neue Art von Aloe L. anerkannt: Aloe sharoniae N.R. Crouch \& Gideon F. Sm. Das Taxon war bisher als A. cooperi Baker subsp. pulchra Glen \& D.S.Hardy bekannt, und wird hier in den Rang einer Art erhoben. Es unterscheidet sich von $A$. cooperi Baker durch Blätter, die einheitlich in den oberen $2 / 3$ des Blattrandes keine Zähne haben, und die basal mit weissen, warzigen Flecken besetzt sind. Darüberhinaus sind die Blätter stets stark gekielt und zweizeilig angeordnet. Typischerweise zeigen die Pflanzen im Vergleich mit typischen $A$. cooperi sowohl weniger Blätter wie auch weniger Blüten pro Blütenstand.

\section{Introduction}

Perhaps not surprisingly, most new species of Aloe described from South Africa in the last decade belong to one of the most cryptic of the formal groups recognized in this diverse genus - which includes the true grass aloes and leptoaloes (Smith, 2003; Van Jaarsveld \& Van Wyk, 2006; Klopper \& Smith, 2010; Smith \& Crouch, 2010). Shortly after submitting the description of A. nicholsii Gideon F.Sm. \& N.R.Crouch for review, that was subsequently published in this journal (Smith \& Crouch, 2010), a further interesting Aloe species (Figure 1) was brought to our notice. It had been noted as occurring in grasslands within the same general region of $\mathrm{Ba}$ banango in southern Zululand, South Africa (Figure 2), but was not found growing sympatrically with $A$. nicholsii. This entity was known previously as A. cooperi Baker subsp. pulchra Glen \& D.S.Hardy but is here elevated to species rank, as A. sharoniae N.R.Crouch \& Gideon F.Sm. following intensive fieldwork in several subpopulations. Aloe sharoniae - the epithet pulchra is unavailable at species rank - differs from A. cooperi Baker (Figure 3) in being less robust and foliose, with leaves always distichous, in having less floriferous inflorescences arranged in distinctly capitate to very shortly elongated racemes, and with the upper $2 / 3$ of its leaf margins devoid of teeth (Table 1). Aloe sharoniae further presents prominently keeled leaves, basally covered below with white, distinctly tuberculate maculations, and which possess rubbery, hair-like marginal bristles (Figure 4) (Glen \& Hardy, 1987; Glen \& Hardy, 2000). The flowers of $A$. sharoniae are slightly inflated in the middle (Figure 5) and its erect buds distinctly glaucous distally (Figure 6). 
Table 1. Differences between Aloe sharoniae and A. cooperi

\begin{tabular}{|c|c|c|}
\hline Character & A. sharoniae & A. cooperi \\
\hline Stems & usually solitary, very rarely clumped & sometimes solitary, usually clumped \\
\hline Leaf arrangement & always distichous & $\begin{array}{l}\text { distichous or spirally twisted to ros- } \\
\text { ulate }\end{array}$ \\
\hline Leaves & $\begin{array}{l}\text { lower surface always prominently } \\
\text { keeled }\end{array}$ & $\begin{array}{l}\text { lower surface variously keeled or } \\
\text { convex }\end{array}$ \\
\hline Leaf margins & $\begin{array}{l}\text { basal } 1 / 4 \text { to } 1 / 3 \text { with rubbery, hair-like } \\
\text { bristles, entire above }\end{array}$ & $\begin{array}{l}\text { dentate for entire length, without } \\
\text { rubbery, hair-like bristles }\end{array}$ \\
\hline Lower basal leaf surfaces & with tuberculate white maculations & white maculations smooth \\
\hline Fertile bracts & clasping the pedicels & flat to U-shaped \\
\hline Perianth & $\begin{array}{l}25-35 \mathrm{~mm} \text { long, bright orange-red, } \\
\text { tip extremity brownish }\end{array}$ & $\begin{array}{l}25-40 \mathrm{~mm} \text { long, salmon-pink to } \\
\text { blood red, tip extremity green }\end{array}$ \\
\hline
\end{tabular}

When first glimpsed in the field A. sharoniae may initially be confused with Aloe kniphofioides Baker, given the generally solitary character of plants, the shortly elongate nature of the racemes, and the relatively long, reddish flowers. On closer examination, however, they are found to be very distinct, for $A$. sharoniae lacks a bulb-like structure, and has prominently keeled leaves with rubbery, hair-like marginal bristles on the lower third. The leaves of $A$. sharoniae are additionally broader, less leathery in texture, and basally covered below with white, distinctly tuberculate maculations. The flowers are also slightly inflated in the middle and less pencil-shaped than those of A. kniphofioides.

\section{Aloe sharoniae N.R.Crouch \& Gideon F.Sm. nom. nov.}

Type: Republic of South Africa, KwaZulu-Natal, 2832 (Mtubatuba). Palm Ridge (-AC), 05-1986, E.R. Harrison 980 (PRE, holo.!).

Basionym: Aloe cooperi Baker subsp. pulchra Glen \& D.S.Hardy in Flow. Pl. Afr. 49: t. 1944 (1987).

Type: as for A. sharoniae.

\section{Description based on material from Babanango region}

Small to medium-sized, herbaceous, slowgrowing, succulent, perennial, grass aloe, total height excluding inflorescence $\pm 300-650 \mathrm{~mm}$, usually solitary, very rarely clumped with up to 8 heads. Roots fusiform, central portion 7-9 $\mathrm{mm}$ in diameter. Stems subterranean, short, stout, \pm 60 $\mathrm{mm}$ long, $\pm 15-25 \mathrm{~mm}$ in diameter. Leaves few, distichous, 6-8(-11), not persistent when dry, narrowly attenuate, tapering to apex, 300-440(-820) $\mathrm{mm}$ long, 16-26(-39) $\mathrm{mm}$ broad at base, basally sheathing, semi-erect, becoming decurved with age, folding over with age; strongly keeled along entire abaxial length, keel tuberculate especially towards base, light green to whitish, leaf castaneous at base below, otherwise mid-green, concolorous, profusely spotted below in basal $1 / 3$ to $1 / 2$ of leaf, basal spots tuberculate, very occasionally spotted adaxially towards base; margins of basal $1 / 4$ to $1 / 3$ of leaf with rubbery, hair-like spines, recurved or decurved, sometimes straight and only recurved at their tips, ivory-coloured to greenishwhite, 3-5 mm long, gradually reducing distally, spines \pm evenly spaced, appearing only as leaves mature, upper $2 / 3$ of leaf margins smooth, Kniphofia-like; leaves start senescing in midMarch, browning from the tips; dry leaf sap translucent. Inflorescence an unbranched raceme, capitate to slightly elongate, $330-590 \mathrm{~mm}$ tall, shorter or marginally taller than the height of rosette; each rosette producing up to 2 racemes. Peduncle basally plano-convex in cross-section with marginal teeth on ridges on lower $1 / 4$, cylindrical above, 300-520 $\mathrm{mm}$ long, 5-8 $\mathrm{mm}$ broad at base, bright to mid-green, dusty bloom lacking, sparsely sterile bracteate, bracts denser towards apical part of inflorescence, withering as flowers mature, turning pale pink from greenish brown, \pm 10 orange-brown nerves, $18-31 \mathrm{~mm}$ long, 7-9 $\mathrm{mm}$ broad at base, tapering to a sharp, harmless tip. Racemes lax, with 8-20 flowers, the flowering portion $30-95 \mathrm{~mm}$ long, $75-95 \mathrm{~mm}$ in diameter; buds erect, lowest open flowers horizontal, becoming pendent. Floral bracts prominent, greenish-brown maturing to orange, amplexicaul around lower $1 / 2$ to $2 / 3$ of pedicel, somewhat papery, apices attenuate, with 6-7 prominent dark orange nerves, 23-30 $\mathrm{mm}$ long. Pedicels orange-red, 33$43 \mathrm{~mm}$ long when flowers open, lengthening in fruit to $42-48 \mathrm{~mm}$. Flowers zygomorphic, unscented, nectariferous, \pm pencil-shaped, marginally widest in middle, narrowing towards 

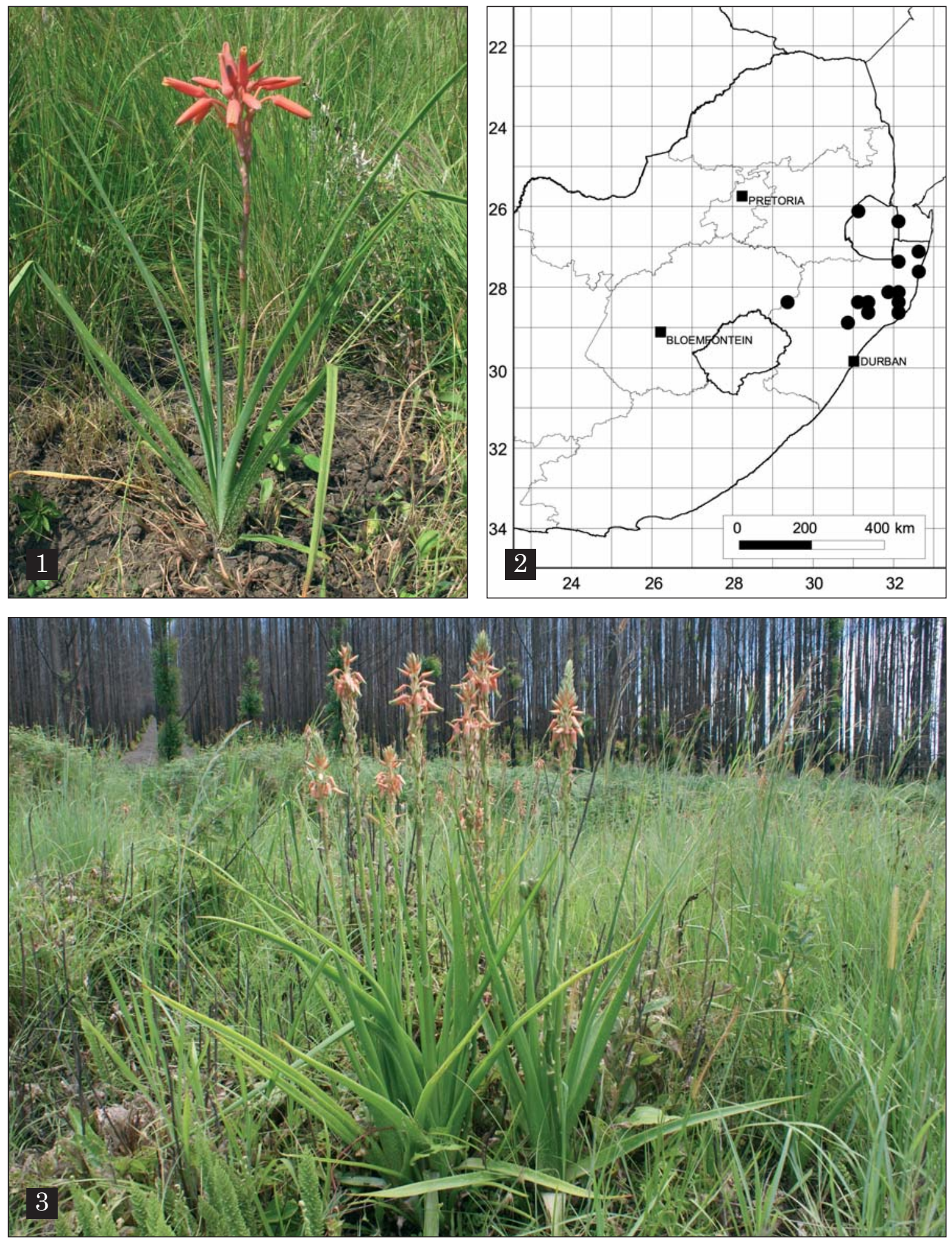

Figure 1. Flowering habit of $A$. sharoniae in moist grassland habitat. Photo: Neil Crouch. Figure 2. Known geographical distribution range of A. sharoniae (๑). Figure 3. Typical A. cooperi. Photo: Gideon Smith. 

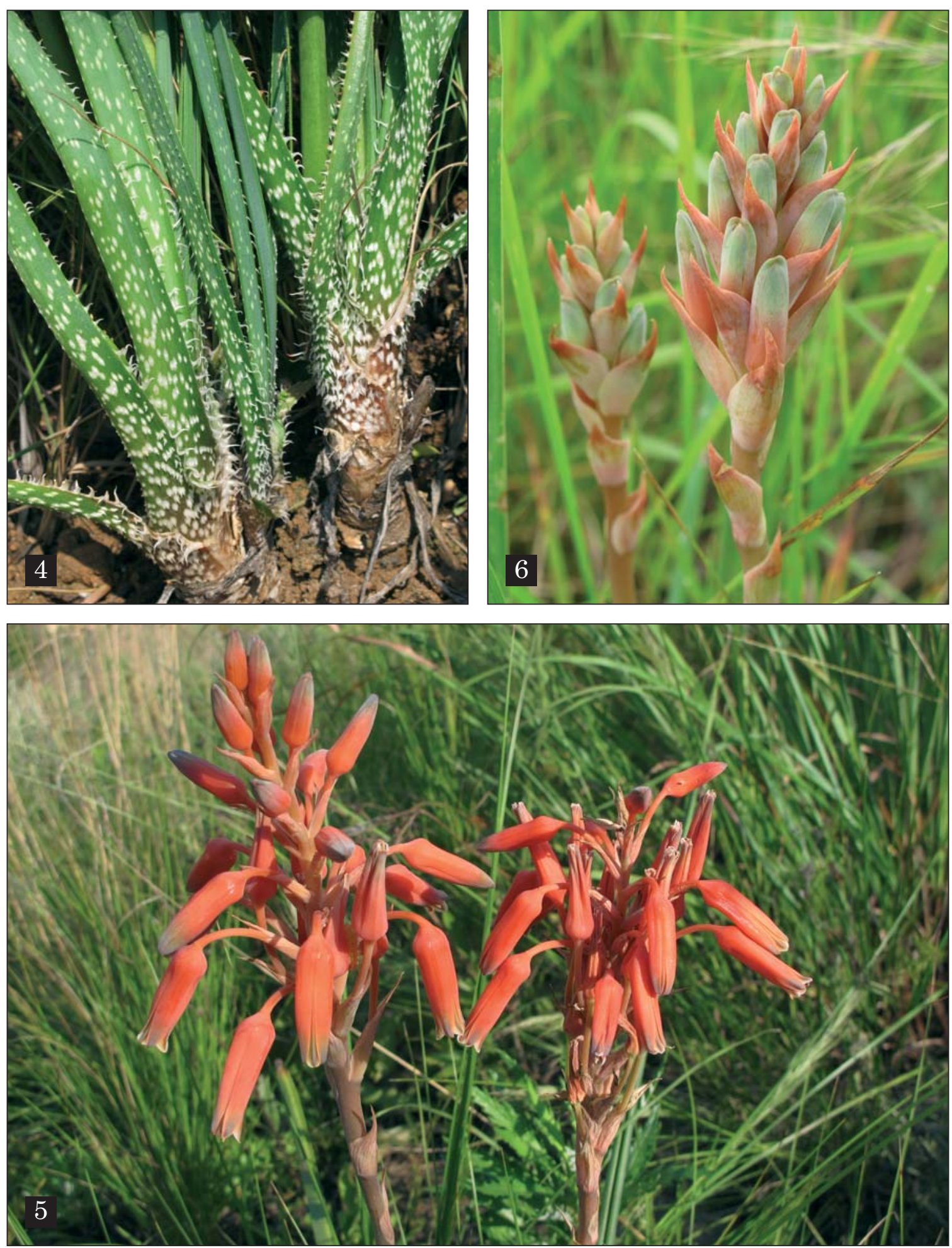

Figure 4. Distichous strongly keeled leaves of $A$. sharoniae; prominent abaxial white maculations and rubbery hair-like marginal bristles. Figure 5. Lax, few-flowered racemes of $A$. sharoniae. Figure 6. Erect pruinose buds of $A$. sharoniae, distinctly glaucous in upper half. Photos: Neil Crouch. 
mouth, bright orange-red, tip extremity yellowish brown to purplish-brown, 25-35 mm long, 6-8 $\mathrm{mm}$ in diameter at ovary; buds pruinose, upper half glaucous green, hidden almost entirely by bracts; flowers slightly indented above ovary; outer segments slightly shorter than inner segments, lorate, free for most of their length, basally fused for $\pm 0.5-1.0 \mathrm{~mm}$, tepal blade uniformly orange-red, acute; inner segments same width as outer, free portion with a prominently keeled, orange-red central nerve, with flesh-coloured border and more obtusely spreading apex, free for most of their length. Stamens 6, hypogynous; filaments cylindrically thread-like to very slightly flattened, light pink, 10-11 mm long, all 6 of \pm equal length, not exserted; anthers $4.0 \mathrm{~mm}$ long, bright orange, dorsifixed, included. Ovary $5 \mathrm{~mm}$ long, $1.6 \mathrm{~mm}$ in diameter, light green-brown; style 13-15 mm long; stigma minute, capitate, included; extending to level with tube mouth during female phase of flower. Fruit an erect, bright green, trilocular capsule, cylindrical, $22-24 \mathrm{~mm}$ long, $8-9 \mathrm{~mm}$ in diameter, apically truncate, dry remains of tepals persisting around fruit for a long time, dehiscing loculicidally, chartaceous to woody when dry. Seeds dark greyish brown, angled, laterally compressed, with off-white wing stretching around periphery of seed, $2.0 \mathrm{~mm}$ long. Flowering time February to March. Chromosome number unknown. (See Figures 1, and 4-6.)

\section{Habitat}

Aloe sharoniae has been noted growing in open grassland on all slope aspects, although moister sites are evidently preferred in the main; this taxon occurs at altitudes of between 45 and 1700 $\mathrm{m}$. Plants respond well to burns hot enough to remove all leaves, and have been noted to flower well in the following season. This characteristic is shared with many other leptoaloes (Craib, 2005). When not in bloom plants are very difficult to locate given their grass-like appearance. Mostly, plants occur singly in fairly close proximity to each other, although plants with up to eight offshoots at ground level have also rarely been encountered. In the Babanango region a total of less than 100 individual plants at six separate subpopulations are known to survive within a regional landscape that has been largely transformed by agricultural and silvicultural activities. Plant associates include Merwilla plumbea in rockier sites, but more usually Agapanthus campanulatus, Dicoma zeyheri, Eriosema cordatum and Berkheya speciosa. Given the cryptic nature of plants when not in flower, range extensions beyond that indicated (Figure 2) are not impossible.

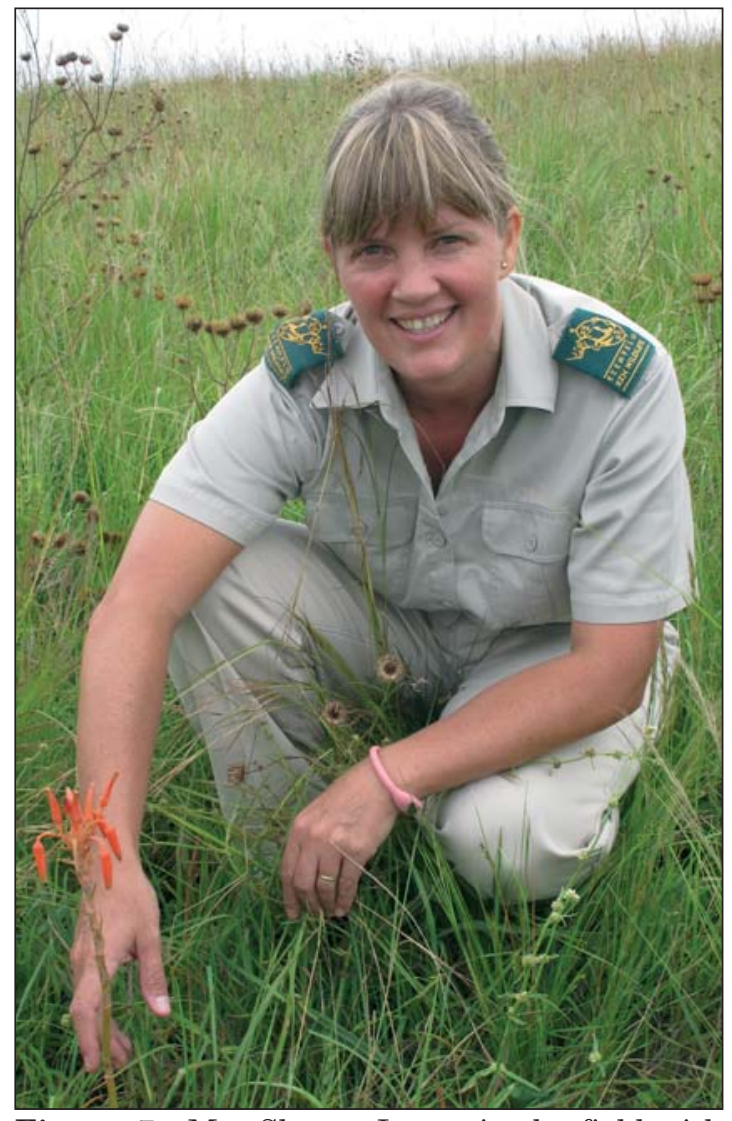

Figure 7. Mrs Sharon Louw, in the field with A. sharoniae, 11 March 2011. Photo: Neil Crouch.

\section{Eponymy}

The epithet pulchra has previously been used at species rank in Aloe (see Rowley \& Newton (1975) for a discussion), and as such is unavailable; we here rename this distinctive entity for Mrs Sharon Louw of Eshowe, KwaZulu-Natal (Figure 7), whose fieldwork at Babanango helped focus our attention on this species. She is a Specialist Research Technician and active field biologist with Ezimvelo KZN Wildlife, the provincial conservation authority.

\section{Acknowledgements}

Mr Richard Palthe, Mr Terence Newton and Ms Lize Shaw of Mondi, Mr Guy Upfold of Mtunzini, and Mr James Harvey of Pietermaritzburg are thanked for field-based assistance. Mrs Ronell Klopper of SANBI (National Herbarium, Pretoria) is thanked for preparing the map. Dr Colin C. Walker kindly assisted with locating pertinent literature. Dr Andreas Jürgens kindly provided an amendment to the German summary. An anonymous referee is thanked for constructive comments on the manuscript. 


\section{References}

Craib, C. (2005). Grass aloes of the South African veld. Umdaus Press, Hatfield, Pretoria.

Glen, H.F. \& HaRdY, D.S. (1987). Aloe cooperi subsp. pulchra. Flow. Pl. Afr. 49: t. 1944.

Glen, H.F. \& HaRdy, D.S. (2000). Aloaceae (First part): Aloe. Flora of southern Africa 5(1): 1167.

KLOPPER, R.R. \& Smith, G.F. (2010). Aloe neilcrouchii, a new robust leptoaloe from KwaZulu-Natal, South Africa. Bothalia 40: 117-120.

Rowley, G.D. \& Newton, L.E. (1975). Liliaceae. Repert. Pl. Succ. 24: 15-17.
Smith, G.F. (2003). Aloe craibii Gideon F.Sm. (Asphodelaceae: Alooideae): a new species of grass aloe from the Barberton Centre of Endemism, Mpumalanga, South Africa. Bradleya 21: 25-28.

Smith, G.F. \& Crouch, N.R. (2010). Aloe nicholsii Gideon F.Sm. \& N.R.Crouch (Asphodelaceae): a new leptoaloe from KwaZulu-Natal, South Africa. Bradleya 28: 103-106.

VAN JAARSVELD, E.J. \& VAN WYK, A.E. (2006). Aloe challisii, a new cliff-dwelling aloe from Mpumalanga, and a checklist of the obligate cliff-dwelling aloes in South Africa and Namibia. Aloe 43: 36-41. 